At-Tijaroh : Jurnal Ilmu Manajemen dan Bisnis Islam
Volume 6 Nomor 2 Ed. Juli-Desember 2020: Hal 230-250
p-ISSN : $2356-492 x$
e-ISSN : 2549-9270

\title{
PEMETAAN INDUSTRI KREATIF DI KOTA CIREBON (PROSPEK DAN TANTANGANNYA DALAM UPAYA PENINGKATAN EKONOMI MASYARAKAT)
}

\author{
Wartoyo', Nur Haida² $^{2}$ \\ ${ }^{1}$ IAIN Syekh Nurjati Cirebon, 2IAI Bunga Bangsa Cirebon \\ ${ }^{1} \mathrm{Jl}$. Perjuangan no 01 By Pass Sunyaragi Kesambi Cirebon Jawa Barat \\ 2Jl. Widarasari III Tuparev Kota Cirebon \\ 1wartoyo1o@gmail.com \\ 2nurhaida26684@gmail.com
}

\begin{abstract}
Cirebon City has a very strategic geographical location because it is located in the path of the crossing of goods and services through the north coast (pantura). This study uses a survey method with a qualitative approach and descriptive analysis. The results of this study indicate that the culinary sub-sector is the largest sub-sector of the other types of creative economy in the city of Cirebon with a percentage reaching $42 \%$, followed by the Fashion economy 15\%, Craft Economy, Architecture and Visual Design respectively by 12\%. whereas for the most creative economy actors, the District Prosecutor's Office reached 45.8\%, followed by Harjamukti District 37\%, Pekalipan District 25\%, Kesambi District 10.7\% and Lemahwutut District 6\%. From these data, the culinary economy, Fashion and Craft can be used as a superior subsector for the City of Cirebon, while the District Prosecutors and District Kesambi can be used as a creative economic center in the city of Cirebon. The potential to make the Creative economy as one of the sectors boosting the local is good cooperation between related parties so that the synergy and management of the management run in harmony and balance.
\end{abstract}

Keywords: Creative Economy, Economic Development, Economic Innovation

\begin{abstract}
Abstrak
Kota Cirebon memiliki letak geografis yang sangat strategis karena terletak di jalur perlintasan barang dan jasa melalui pantai utara (pantura). Penelitian ini menggunakan metode survey dengan pendekatan kualitatif dan analisis deskriptif. Hasil penelitian ini menunjukkan bahwa Sub sektor kuliner merupakan sub sektor paling besar dari jenis ekonomi kreatif lainnya di Kota Cirebon dengan persentase mencapai 42\%, disusul kemudian oleh ekonomi Fashion 15\%, Ekonomi Kriya, Arsitektur dan Desain Visual masing-masing sebesar 12\%. sedangkan untuk wilayah yang paling banyak pelaku ekonomi kreatifnya adalah Kecamatan Kejaksan dengan persentasi mencapai 45,8\%, disusul Kecamatan Harjamukti 37\%, Kecamatan Pekalipan 25\%, Kecamatan Kesambi 10,7\% dan Kecamatan Lemahwungkuk 6\%. Dari data tersebut maka ekonomi kuliner, Fashion dan Kriya dapat dijadikan sebagai subsektor unggulan untuk Kota Cirebon, sedangkan Kecamatan Kejaksan dan Kecamatan Kesambi dapat dijadikan sebagai pusat ekonomi kreatif yang ada di Kota Cirebon. Potensi untuk menjadikan ekonomi Kreatif sebagai salah satu sektor pendongkrak ekonomi lokal di Kota Cirebon sangatlah besar, dengan syarat terjadi kerjasama yang baik antara para pihak terkait sehingga sinergi dan manajemen pengelolaannya berjalan selaras dan seimbang.
\end{abstract}

Kata Kunci : Ekonomi Kreatif, Pembangunan ekonomi, Inovasi Ekonomi 


\section{PENDAHULUAN}

Istilah Ekonomi kreatif berkembang dari konsep modal berbasis kreatifitas yang dapat berpotensi meningkatkan pertumbuhan ekonomi di suatu daerah. Menurut Presiden Susilo Bambang Yudhoyono, ekonomi kreatif merupakan ekonomi gelombang ke-4 yang mana kelanjutan dari ekonomi gelombang ketiga dengan orientasi pada kreativitas, budaya, serta warisan budaya dan lingkungan (Negara, n.d.). Pada era ekonomi kreatif nilai barang dan jasa sangat ditentukan sejauh mana sumber daya manusia mampu memanfaatkan teknologi, kreativitas dan inovasi. Industri bersaing dipasar global tidak hanya mengandalkan harga dan kualitas, tetapi bersaing dengan basis teknologi, inovasi, kreativitas dan imajinasi (Asyhari \& Wasitowati, 2015). Dalam era globalisasi, pemerintah menyadari bahwa perbaikan ekonomi yang lebih baik, untuk meraih keunggulan sangat diperlukan. Oleh karena itu industri kreatif yang berfokus pada penciptaan barang dan jasa dengan mengandalkan keahlian, bakat dan kreativitas sebagai kekayaan intelektual, memiliki prospek yang cukup baik untuk dikembangkan. Peranan ekonomi kreatif sangat penting dalam perekonomian nasional (Berita - E-Commerce Untuk UMKM Dan Pertumbuhan Ekonomi Indonesia, n.d.).

Mengutip dari Cetak Biru Ekonomi Kreatif 2025, ekonomi kreatif merupakan suatu penciptaan nilai tambah (ekonomi, sosial, budaya, lingkungan) berbasis ide yang lahir dari kreativitas sumber daya manusia (orang kreatif) dan berbasis pemanfaatan ilmu pengetahuan, termasuk warisan budaya dan teknologi. Kreativitas tidak sebatas pada karya yang berbasis seni dan budaya, namun juga dapat berbasis ilmu pengetahuan dan teknologi, engineering dan ilmu telekomunikasi. Terdapat 3 hal pokok yang menjadi dasar dari ekonomi kreatif, antara lain kreativitas, inovasi dan penemuan. Berdasarkan hasil penelitian dari Badan Ekonomi Kreatif (Bekraf) dan Badan Pusat Statistik (BPS) pada tahun 2016, ekonomi kreatif memberikan kontribusi sebesar 922.59 miliar rupiah atau sebesar 7,44 persen terhadap Produk Domestik Bruto (PDB) nasional (Burhanudin, 2020).

Adanya otonomi daerah mengharuskan tiap daerah untuk selalu mengembangkan potensi-potensi ekonomi yang dimilikinya. Pengembangan dan pembangunan daerah juga harus disesuaikan dengan kondisi serta aspirasi masyarakat yang tumbuh dan berkembang (Ayu Monica et al., 2019). Kota Cirebon sebagai kota yang sedang berkembang juga perlu mengidentifikasi potensi-potensi yang ada dalam sektor ekonomi kreatif yang ada. Proses identifikasi ini sangat berguna nantinya karena dapat dijadikan bahan dasar untuk melakukan analisis (Siwu, 2019). Pembuatan kebijakan atau pengambilan keputusan yang signifikan bagi pertumbuhan ekonomi kreatif di Kota ini. Kota Cirebon memiliki letak geografis yang sangat strategis karena terletak di jalur perlintasan barang dan jasa melalui pantai utara (pantura) yang menghubungkan wilayah bagian barat yang menjadi pusat perputaran ekonomi nasional yaitu DKI Jakarta, Bandung, dan bahkan daerah-daerah di Sumatera dan sekitarnya dengan wilayah pemasok kebutuhan dan komoditas di bagian timur seperti daerah daerah di Propinsi 

Tantangannya Dalam Upaya Peningkatan Ekonomi Masyarakat)

jawa Tengah seperti Brebes, Tegal, Semarang dan daerah-daerah lainnya (1. Letak Geografis - Pemerintah Daerah Kota Cirebon, n.d.). Dengan letak yang sangat strategis tersebut Kota Cirebon seyogyanya mampu memanfaatkan dengan baik setiap peluang yang dimiliki, terutama peluang ekonomi yang begitu besar jika mampu memanfaatkan dan mengelolanya dengan baik.

Besarnya potensi industri kreatif di Kota Cirebon belum dilirik oleh pemerintahan Kota Cirebon sebagai salah satu faktor yang dapat memberikan dan mendongkrak PDRB maupun PAD Kota Cirebon tentu cukup disayangkan. Hal ini didukung oleh berbagai pihak termasuk HIPMI Kota Cirebon (Hanya Industri Kreatif Yang Dapat Berkembang Di Kota Cirebon, n.d.; HIPMI Dorong Pengembangan Industri Kreatif Di Cirebon | Ekonomi, 2017). Sebab kota Cirebon memiliki banyak potensi dan sumberdaya yang dapat dijadikan daya tarik maupun keunggulan dalam industri kreatif. Peluang untuk pengembangan dan pertumbuhan ekonomi kreatif di Kota Cirebon masih dapat ditingkatkan, karena banyak potensi-potensi yang telah terdata belum tergarap dengan baik, selain itu diperkirakan masih banyak potensi-potensi yang bahkan belum terdata dengan baik dalam database perekonomian Kota Cirebon. Jikapun ada data mengenai ekonomi kreatif di berbagai dinas terkait di Kota Cirebon data-data tersebut masih bersifat lokal, digunakan secara terbatas di dinas yang bersangkutan, serta belum menggambarkan secara utuh keadaan ekonomi kreatif di Kota Cirebon. Keterbatasan data ini ternyata memengaruhi regulasi dan aturan yang dibuat setelahnya. Karena data yang digunakan belum bersifat umum, maka regulasi dan peraturan yang dibuatpun masih bersifat lokal. Sehingga membatasi perkembangan ekonomi kreatif yang ada, karena dapat menjadi satu subsektor ekonomi kreatif yang telah dikembangkan oleh dinas yang satu kemudian dikembangkan lagi oleh dinas yang lain, sedangkan Subsektor ekonomi kreatif yang lain tidak tersentuh sama sekali.

Berbagai masalah yang dihadapi dalam pengembangan ekonomi kreatif di Kota Cirebon salah satunya bersumber dari minimnya regulasi dan peraturan yang sistemasis dan bersifat general dalam menghadapi masalah-masalah yang telah terdata maupun belum terdata. Oleh karena itu menjadi keharusan diadakannya sebuah penelitian untuk mengembangkan ekonomi kreatif di Kota Cirebon yang tujuannya adalah menggali informasi dan mengidentifikasi potensi ekonomi kreatif yang ada, kemudian merekap masalah-masalah yang ditemui dalam perkembangannya, sehingga dengan data tersebut dinas-dinas terkait dapat menentukan regulasi yang tepat untuk menyelesaikan permasalahan tersebut.

Dengan demikian diperlukan adanya suatu kajian dan penelitian terkait pemetaan industri kreatif yang ada di kawasan ini. Sampai saat ini belum ada gambaran yang jelas mengenai kondisi industri kreatif di Kota Cirebon yang dapat dijadikan bahan dasar untuk melakukan analisis, pembuatan kebijakan atau pengambilan keputusan yang signifikan bagi pertumbuhan ekonomi kreatif di kota ini. Untuk itu, diperlukan adanya kajian pengembangan 
industri kreatif dalam meningkatkan ekonomi Kota Cirebon. Selain itu output kajian ini merupakan kontribusi bagi pihak terkait khususnya pemerintah sebagai acuan dalam meningkatkan peran industri kreatif dalam pembangunan ekonomi nasional. Sasaran dari kegiatan ini adalah tersusunnya profil industri kreatif Kota Cirebon yang berorientasi pada potensi keunikan industri unggulan, potensi lokal, keterpaduan, pelestarian lingkungan, peluang investasi serta peningkatan kesejahteraan masyarakat dan ekonomi daerah.

Industri kreatif didefinisikan sebagai industri yang berfokus pada kreasi dan eksploitasi karya kepemilikan intelektual seperti seni rupa, film dan televisi, piranti lunak, permainan, atau desain fesyen, dan termasuk layanan kreatif antar perusahaan seperti iklan, penerbitan, dan desain (Gaunt, n.d.). Dari definisi tersebut di atas dapat disimpulkan bahwa terdapat tiga (3) poin terpenting dalam industri kreatif yaitu a) Kreativitas, keterampilan dan talenta : Berbasis pada otak manusia yaitu kreativitas (baik artistik maupun non-artistik seperti sains). Berbeda dengan sumber daya alam yang akan terus berkurang, kreativitas adalah sumber daya yang tidak terbatas, b) Peningkatan kesejahteraan: suatu konsep dalam meraih kesejahteraan, dan c) Penciptaan dan eksploitasi berbasis HKI.

Keberhasilan industri kreatif tentunya akan ditentukan oleh pelakunya/pekerja kreatifnya. Pekerja kreatif ditetapkan berdasar pekerjaan yang utama yang dilakukan. Pekerja sebagai pemain piano diklasifikasikan sebagai musisi. Pelaku industri kreatif dikelompokkan menjadi a) Semua pekerja yang dipekerjakan di industri kreatif (misal: musisi, satpam, akuntan, manajer, dsb), b) Semua pekerja kreatif dan tidak bekerja untuk industri kreatif (misal: guru piano); c) Semua orang dengan pekerjaan kreatif sampingan, misal: menghasilkan karya seni di waktu luang, atau sebagai hobi (Erimurti, 2008).

Produk adalah segala sesuatu yang dapat ditawarkan kepada pasar untuk memuaskan keinginan atau kebutuhan konsumen. Produk dapat kita klasifikasikan menjadi tiga berdasarkan 1) daya tahan produk, 2) produk konsumen, dan 3) produk industri. Berdasarkan daya tahannya, meliputi 1) produk yang memiliki daya tahan jangka waktu lama, dan 2) produk yang memiliki daya tahan jangka pendek, sedangkan jasa layanan termasuk dalam golongan produk yang tidak nyata. Produk konsumen dikelompokkan menjadi: 1) Produk praktis (convenience goods), produk yang sering dibeli oleh konsumen.; 2) Produk Umum (shopping goods), proses pembeliannya diperlukan seleksi dengan cara membandingkan kesesuaian, kualitas dan gaya (style); 3) Produk Khusus (specialty goods), memiliki karakteristik keunikan atau merk khusus, dan harga khusus ; 4) Produk Sangat Khusus (unsuoght goods) yaitu produk yang jarang dibeli, bahkan tidak pernah memikirkan untuk membelinya. Sedangkan produk kerajinan dan karya seni termasuk dalam kategori produk khusus. Produk industri adalah produk yang diklasifikasikan berdasar proses produksi, dibagi menjadi : a) Bahan Baku dan Suku Cadang (materials and parts), b) Barang-barang Modal, dan c) Jasa Layanan dan Pasokan (Erimurti, 2008) 


\section{METODE PENELITIAN}

Untuk mengetahui bagaimana gambaran industry kreatif yang ada di Kota Cirebon, metode pemetaan yang digunakan adalah metode pemetaan social (socialmapping). Dalam makalah ini pemetaan sosial (social mapping) didefinisikan sebagai proses penggambaran masyarakat yang sistematik serta melibatkan pengumpulan data dan informasi mengenai masyarakat termasuk di dalamnya profile dan masalah sosial yang ada pada masyarakat tersebut. Pemetaan sosial dapat disebut juga sebagai social profiling atau "pembuatan profile suatu masyarakat (McMurtry et al., 1993).

Penelitian ini merupakan jenis penelitian lapangan (field research) dengan menggunakan metode survey. Sedangkan metode pendekatannya menggunakan pendekatan kualitatif - deskripftif, metodologi penelitian kualitatif adalah suatu penelitian ilmiah yang bertujuan untuk memahami suatu fenomena dalam konteks sosial secara alamiah dengan mengedepankan proses interaksi komunikasi yang mendalam antara peneliti dengan fenomena yang diteliti. Alamiah disini mempunyai arti bahwa penelitian kualitatif dilakukan dalam lingkungan yang alami tanpa adanya intervensi atau perlakuan yang diberikan oleh peneliti. Sangat tidak dibenarkan untuk memanipulasi atau mengubah latar penelitian (Moleong, 2005).

\section{Peta Industri Kreatif di Kota Cirebon}

Perpres Nomor 72 Tahun 2015 tentang Perubahan Atas Peraturan Presiden Nomor 6 Tahun 2015 Tentang Badan Ekonomi Kreatif telah mengklasifikasi ulang sub-sektor industri kreatif dari 15 sub-sektor menjadi 16 sub-sektor, yaitu arsitektur; disain interior; disain komunikasi visual; disain produk; film, animasi, dan video; fotografi; kriya; kuliner; musik; fesyen; games dan aplikasi; penerbitan; periklanan; televisi dan radio; seni pertunjukan; dan seni rupa. Ada 4 sumber data yang digunakan dalam kegiatan klasifikasi Ekonomi kreatif di Kota Cirebon yaitu data pelaku UMKM yang tercatat di Disperindag, data pelaku Industri yang tercatat di Disperindag, data pelaku usaha yang tercatat di BPMPP, dan data pelaku usaha yang tercatat di masing-masing kecamatan yang ada di Kota Cirebon. Adapun Rinciannya adalah sebagai berikut:

Tabel 1.

Klasifikasi Ekonomi Kreatif Berdasarkan Data Pelaku UMKM yang Tercatat di DISPERINDAG 


\begin{tabular}{|c|c|c|c|c|c|c|c|c|c|c|c|c|c|c|c|c|c|}
\hline $\begin{array}{c}\text { Sumber Data } \\
\text { Disperindag } \\
\text { (Industri) }\end{array}$ & 1 & 2 & 3 & 4 & 5 & 6 & 7 & 8 & 9 & 10 & 11 & 12 & 13 & 14 & 15 & 16 & \\
\hline Harjamukti & - & - & 3 & 1 & - & 10 & - & - & 2 & 52 & - & - & - & 1 & - & - & 69 \\
\hline Kejaksan & - & - & - & 1 & - & 5 & - & - & 1 & 26 & - & - & - & - & - & - & 33 \\
\hline Kesambi & - & - & 1 & 2 & - & 6 & - & - & 3 & 48 & - & - & - & - & 2 & - & 62 \\
\hline Lemahwungkuk & - & - & - & - & - & 1 & - & - & 2 & 26 & - & - & - & - & - & - & 29 \\
\hline Pekalipan & - & - & - & - & - & 2 & - & - & 3 & 23 & - & - & - & - & - & - & 28 \\
\hline Total & o & 0 & 4 & 4 & o & 24 & 0 & o & 11 & 175 & 0 & 0 & 0 & 1 & 2 & 0 & 221 \\
\hline
\end{tabular}

Keterangan :

1. Aplikasi dan Pengembang Permainan; 2. Arsitektur; 3. Desain Interior; 4. Desain Komunikasi Visual; 5.Desain Produk; 6. Fashion; 7. Film, Animasi dan Video; 8. Fotografi; 9. Kriya; 10. Kuliner; 11. Musik; 12. Penerbitan; 13. Periklanan; 14. Seni Pertunjukan; 15. Seni rupa; 16. Televisi dan Radio

Dari Tabel 1 terlihat bahwa berdasarkan data DISPERINDAG Kota Cirebon pelaku UMKM yang berasal dari data terdapat total 221 industri kreatif yang tersebar di wilayah Kota Cirebon dengan persentase 79\% merupakan sub sektor kuliner, 10,85\% sub sektor fashion, $5 \%$ sub sektor kriya dan sisanya kurang dari $5 \%$ adalah desain interior dan desain visual, seni rupa dan seni pertunjukan (showbiz).

Tabel 2.

\section{Klasifikasi Ekonomi kreatif berdasarkan data pelaku Industri yang Tercatat di DISPERINDAG}

\begin{tabular}{|c|c|c|c|c|c|c|c|c|c|c|c|c|c|c|c|c|c|}
\hline \multirow{2}{*}{$\begin{array}{c}\text { Sumber Data } \\
\text { Disperindag } \\
\text { (UMKM) }\end{array}$} & \multicolumn{16}{|c|}{ Jenis Ekonomi Kreatif } & \multirow[t]{2}{*}{ Total } \\
\hline & 1 & 2 & 3 & 4 & 5 & 6 & 7 & 8 & 9 & 10 & 11 & 12 & 13 & 14 & 15 & 16 & \\
\hline Harjamukti & - & 3 & - & 22 & - & 12 & - & - & 16 & 9 & - & - & - & - & - & - & 62 \\
\hline Kejaksan & - & - & - & 11 & - & 8 & - & - & 7 & 12 & - & - & - & - & - & - & 38 \\
\hline Kesambi & - & - & - & 25 & - & 18 & - & - & 22 & 43 & - & - & - & 3 & - & - & 111 \\
\hline Lemahwungkuk & - & 2 & - & 10 & 1 & $\begin{array}{l}3 \\
2\end{array}$ & - & - & 22 & 40 & - & - & - & 3 & - & - & 110 \\
\hline Pekalipan & - & - & - & 22 & - & 11 & - & - & 15 & 9 & - & - & - & - & - & - & 57 \\
\hline Total & 0 & 5 & 0 & 90 & 1 & 81 & 0 & o & 82 & $\begin{array}{l}11 \\
3\end{array}$ & 0 & 0 & 0 & 6 & 0 & 0 & 378 \\
\hline
\end{tabular}

Keterangan: 1. Aplikasi dan Pengembang Permainan; 2. Arsitektur; 3. Desain Interior; 4. Desain Komunikasi Visual; 5.Desain Produk; 6. Fashion; 7. Film, Animasi dan Video; 8. Fotografi; 9. Kriya; 10. Kuliner; 11. Musik; 12. Penerbitan; 13. Periklanan; 14. Seni Pertunjukan; 15. Seni rupa; 16. Televisi dan Radio

Tabel 2, menunjukkan bahwa pelaku Industri kreatif berdasarkan pelaku industri kreatif menurut data DISPERINDAG Kota Cirebon sebagian besar merupakan pelaku usaha kuliner 29,9\%, 23,8\% merupakan pelaku usaha Desain Komunikasi Visual, 21,7\% merupakan pelaku usaha Kriya, 21,4\% Fashion, dan sisanya kurang dari 5\% adalah pelaku usaha seni pertunjukan dan arsitektur.

At-Tijaroh : Jurnal Ilmu Manajemen dan Bisnis Islam, Volume 6, Nomor 2 Tahun 2020 http://jurnal.iain-padangsidimpuan.ac.id/index.php/attijaroh 
Berdasarkan dua data tersebut, dapat disimpulkan bahwa baik pelaku UMKM maupun pelaku industri yang ada di Kota Cirebon sebagian besar di dominasi oleh sub sektor kuliner yang dapat menjadi sub sektor industri kreatif unggulan bagi Kota Cirebon.

\section{Tabel 3.}

Klasifikasi Ekonomi kreatif berdasarkan data pelaku Usaha yang tercatat di BPMPP

\begin{tabular}{|c|c|c|c|c|c|c|c|c|c|c|c|c|c|c|c|c|c|}
\hline \multirow{2}{*}{$\begin{array}{c}\text { Sumber Data } \\
\text { Pelaku USaha } \\
\text { (BPMPP) }\end{array}$} & \multicolumn{16}{|c|}{ Jenis Ekonomi Kreatif } & \multirow[t]{2}{*}{ Total } \\
\hline & 1 & 2 & 3 & 4 & 5 & 6 & 7 & 8 & 9 & 10 & 11 & 12 & 13 & 14 & 15 & 16 & \\
\hline Pelaku Usaha di & o & 79 & 12 & 8 & 6 & 34 & o & 2 & 11 & 67 & 2 & 0 & 12 & o & 0 & 0 & 233 \\
\hline
\end{tabular}

Keterangan: 1.Aplikasi dan Pengembang Permainan; 2. Arsitektur; 3. Desain Interior; 4. Desain Komunikasi Visual; 5.Desain Produk; 6. Fashion; 7. Film, Animasi dan Video; 8. Fotografi; 9. Kriya; 10. Kuliner; 11. Musik; 12. Penerbitan; 13. Periklanan; 14. Seni Pertunjukan; 15. Seni rupa; 16. Televisi dan Radio

Sedangkan menurut data BPMPP menunjukkan hasil yang sedikit berbeda dengan data dari Desperindak Kota Cirebon, menurut data BPMPP sebaran pelaku industri kreatif di Kota Cirebon lebih merata dengan 33,9\% merupakan pelaku usaha arsitektur, 28,7\% pengusaha kuliner, 14,6\% Fashion, masing-masing 5\% desain interior dan periklanan, serta kurang dari 3\% fotografi, desain produk dan musik. Perbedaan ini data antara DISPERINDAG dengan BPMPP terjadi disebabkan oleh perbedaan metode dan waktu pendataan yang dilakukan.

Tabel 4.

Klasifikasi Ekonomi kreatif berdasarkan data pelaku Usaha yang Tercatat di Masing Kecamatan yang Ada di Kota Cirebon

\begin{tabular}{|c|c|c|c|c|c|c|c|c|c|c|c|c|c|c|c|c|c|}
\hline \multirow{2}{*}{$\begin{array}{c}\text { Sumber Data } \\
\text { dari Kecamatan }\end{array}$} & \multicolumn{16}{|c|}{ Jenis Ekonomi Kreatif } & \multirow[t]{2}{*}{ Total } \\
\hline & 1 & 2 & 3 & 4 & 5 & 6 & 7 & 8 & 9 & 10 & 11 & 12 & 13 & 14 & 15 & 16 & \\
\hline Harjamukti & - & 17 & 1 & 9 & - & 1 & 1 & - & 1 & 3 & - & - & 4 & - & - & - & 37 \\
\hline Kejaksan & - & 8 & - & - & 1 & 7 & - & - & 3 & 50 & - & 1 & 3 & 1 & - & 3 & 77 \\
\hline Kesambi & - & - & - & - & - & 1 & - & - & - & 16 & - & - & - & - & 1 & - & 18 \\
\hline Lemahwungkuk & - & 4 & - & 2 & 1 & 2 & - & - & 2 & - & - & - & - & - & - & - & 11 \\
\hline Pekalipan & - & 1 & 1 & 7 & - & 1 & - & 2 & 8 & - & - & - & 4 & - & 1 & - & 25 \\
\hline Total & O & 30 & 2 & 18 & 2 & 12 & 1 & 2 & 14 & 69 & 0 & 1 & 11 & 1 & 2 & 3 & 168 \\
\hline
\end{tabular}

Keterangan : 1.Aplikasi dan Pengembang Permainan; 2. Arsitektur; 3. Desain Interior; 4. Desain Komunikasi Visual; 5.Desain Produk; 6. Fashion; 7. Film, Animasi dan Video; 8. Fotografi; 9. Kriya; 10. Kuliner; 11. Musik; 12. Penerbitan; 13. Periklanan; 14. Seni Pertunjukan; 15. Seni rupa; 16. Televisi dan Radio

Tabel 4. menunjukkan sebaran pelaku usaha kreatif pada setiap kecamatan yang berada di wilayah Kota Cirebon. Dari data yang diperoleh menunjukkan bahwa Kecamatan Kejaksan merupakan daerah yang paling banyak memiliki pelaku industri kreatif denngan jumlah sebanyak 77 pelaku usaha atau 45,8\%. Disusul oleh Kecamatan Harjamukti dan Pekalipan dengan masing-masing 37 dan 25 pelaku usaha kreatif atau 22\% dan 14,8\%. Sedangkan di 
Kecamatan Kesambi dan Lemahwungkuk hanya ada 18 dan 11 pelaku usaha kreatif. Sedangkan untuk presentase sub sektor industri kreatif masih di dominasi oleh industri kuliner sebesar 41\% dan arsitektur sebesar $17.8 \%$.

Tabel 5 .

Rekapitulasi Data Ekonomi Kreatif

\begin{tabular}{|c|c|c|c|c|c|c|c|c|c|c|c|c|c|c|c|c|c|}
\hline \multirow[t]{2}{*}{ Sumber Data } & \multicolumn{16}{|c|}{ Jenis Ekonomi Kreatif } & \multirow[t]{2}{*}{ Total } \\
\hline & 1 & 2 & 3 & 4 & 5 & 6 & 7 & 8 & 9 & 10 & 11 & 12 & 13 & 14 & 15 & 16 & \\
\hline $\begin{array}{l}\text { Pelaku UMKM di } \\
\text { Disperindag }\end{array}$ & o & o & 4 & 4 & o & 24 & 0 & $\mathrm{O}$ & 11 & 175 & 0 & $\mathrm{O}$ & $\mathrm{O}$ & 1 & 2 & o & 221 \\
\hline $\begin{array}{l}\text { Pelaku Industri di } \\
\text { Disperindag }\end{array}$ & o & 5 & o & 90 & 1 & 81 & o & o & 82 & 113 & 0 & 0 & 0 & 6 & 0 & o & 378 \\
\hline $\begin{array}{l}\text { Pelaku Usaha di } \\
\text { BPMPP }\end{array}$ & o & 79 & 12 & 8 & 6 & 34 & $\mathrm{O}$ & 2 & 11 & 67 & 2 & $\mathrm{O}$ & 12 & 0 & 0 & 0 & 233 \\
\hline $\begin{array}{l}\text { Pelaku Usaha di } \\
\text { Kecamatan }\end{array}$ & O & 30 & 2 & 18 & 2 & 12 & 1 & 2 & 14 & 69 & 0 & 1 & 11 & 1 & 2 & 3 & 168 \\
\hline Total & 0 & 114 & 18 & 120 & 9 & 151 & 1 & 4 & 118 & 424 & 2 & 1 & 23 & 8 & 4 & 3 & 1000 \\
\hline
\end{tabular}

Keterangan: 1.Aplikasi dan Pengembang Permainan; 2. Arsitektur; 3. Desain Interior; 4. Desain Komunikasi Visual; 5.Desain Produk; 6. Fashion; 7. Film, Animasi dan Video; 8. Fotografi; 9. Kriya; 10. Kuliner; 11. Musik; 12. Penerbitan; 13. Periklanan; 14. Seni Pertunjukan; 15. Seni rupa; 16. Televisi dan Radio

Tabel 5. merupakan data rekap dari data sebelumnya. Dalam tabel dapat diketahui bahwa pelaku industri kreatif di Kota Cirebon mencapai kurang lebih 1000 pelaku usaha yang tersebar di 6 Kecamatan Kota Cirebon, bila digambarkan dalam diagram batang maka hasilnya akan terlihat sebagaimana gambar 1 di bawah ini :

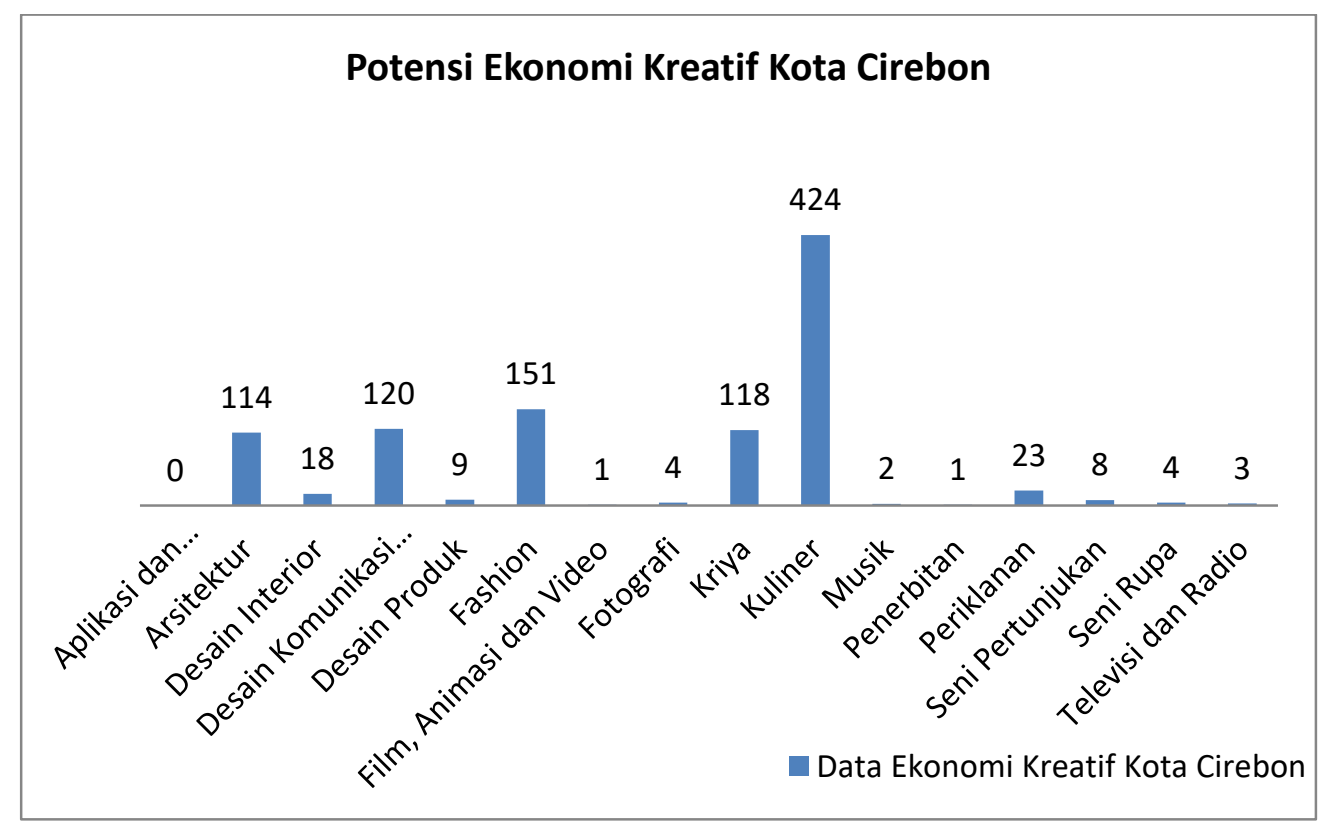

\section{Gambar 1. Data Rekapitulasi jumlah Pelaku dan subsektor industri Kreatif di Kota Cirebon}

Sedangkan untuk melihat data presentase per sub sektornya lebih jelas digambarkan dalam gambar diagram di bawah ini : 


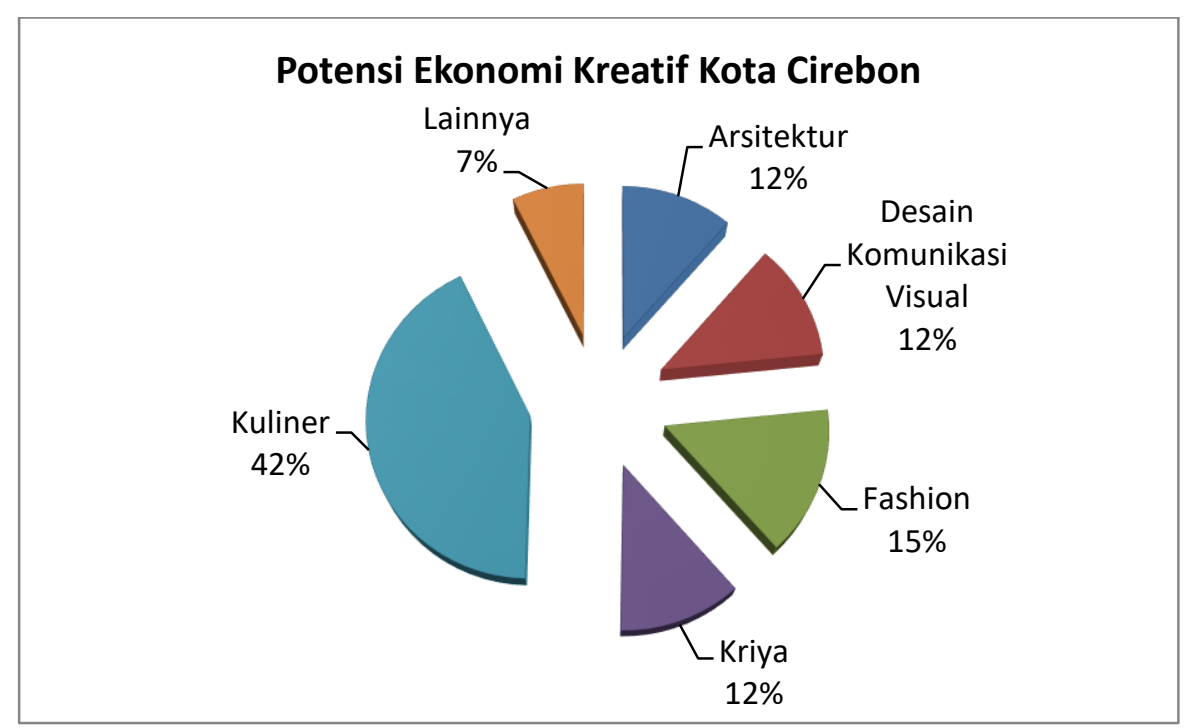

\section{Gambar 2. Persentasi pelaku dan subsektor industri kreatif di Kota Cirebon}

Data penelitian baik yang bersumber dari DISPERINDAG maupun BPMPP menunjukkan bahwa sebagian besar industri kreatif di Kota Cirebon berada pada dapatng usaha kuliner sebesar 42\% dan sebagian besar berada di Kecamatan Kejaksan, Harja Mukti dan Pekalipan. Hasil dari pemetaan ini memberikan gambaran jelas bagi pemerintahan Kota Cirebon untuk fokus dalam menggarap sub sektor kuliner, kriya dan fashion sebagai subsektor industri kreatif unggulan yang memiliki ciri khas dan keistimewaan yang tidak terdapat di daerah-daerah lainnya.

\section{Pemetaan Permasalahan Ekonomi Kreatif di Kota Cirebon}

Besarnya potensi pengembangan industri kreatif di Kota Cirebon yang penyebarannya terdapat di lima kecamatan sebagaimana telah disajikan pada penjelasan sebelumnya, perlu ditindak lanjuti dengan identifikasi permasalahan yang dihadapi dan dialami oleh para pelaku industri kreatif, oleh sebab itu dilakukan penelitian dan pengkajian dengan tujuan untuk mengungkap apa saja permasalahan yang dihadapi dan inisiatif-inisiatif pemecahan masalah dan solusi terhadap permasalahan tersebut yang bersumber dari pelaku usaha langsung dengan menggunakan tehnik wawancara tertutup dengan sebaran form identifikasi usaha ekonomi kreatif Kota Cirebon 2017 adalah sebagai berikut :

$\begin{array}{ll}\text { Kecamatan Pekalipan } & : 13 \text { Informan } \\ \text { Kecamatan Kesambi } & : 15 \text { Informan } \\ \text { Kecamatan Kejaksan } & : 11 \text { Informan } \\ \text { Kecamatan Lemah wungkuk } & : 15 \text { Informan } \\ \text { Kecamatan Harjamukti } & : \text { 10 Informan }\end{array}$

Dengan total keseluruhan informan adalah 64 informan yang menjadi sampel untuk di teliti. 


\section{Identifikasi permasalahan Industri Kreatif Kota Cirebon}

Berdasarkan hasil wawancara secara tertutup terhadap informan didapatkan isian sebagai berikut :

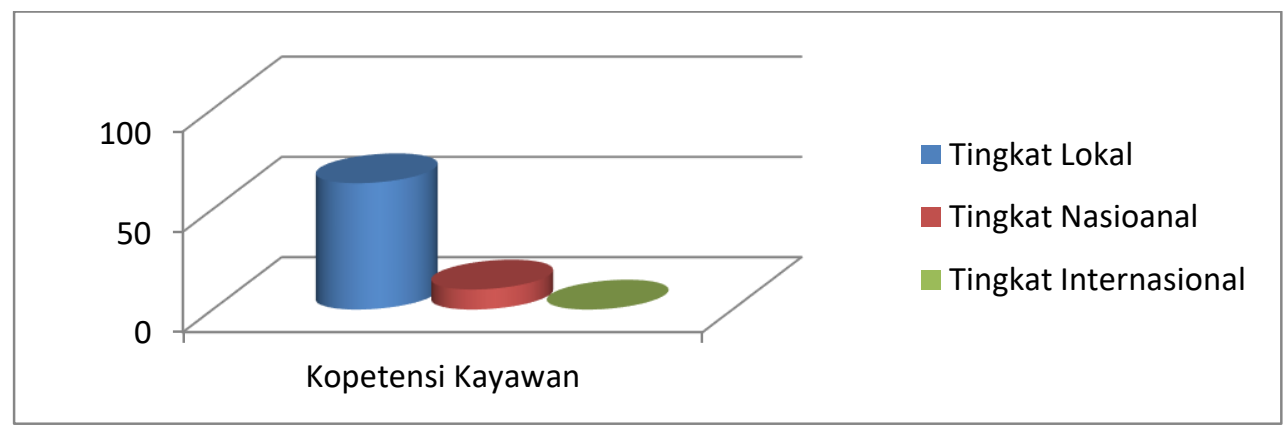

Gambar 3. Kompetensi SDM Industri Kreatif Kota Cirebon

Berdasarkan data di atas di ketahui sebagaian besar karyawan yang bekerja pada pelaku usaha kreatif, karyawan yang mempunyai kompetensi tingkat lokal sebanyak 63 isian informan serta untuk timgkat nasional sebanyak 10 isian informan sedangkan dari total 73 isian informan yang di teliti tidak terdapat satu pelaku usahapun yang memiliki karyawan berkompetensi tingkat internasional.

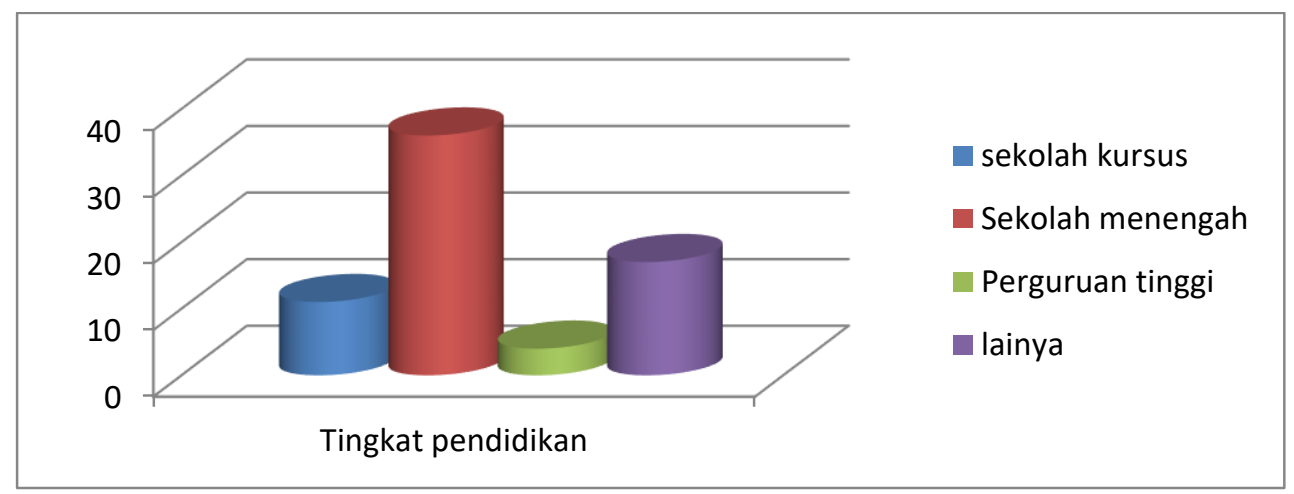

\section{Gambar 4. Tingkat Pendidikan SDM Industri Kreatif Kota Cirebon}

Berdasarkan tingkat lulusan karyawan Pelaku usaha kreatif di kota cirebon, dominan adalah lulusan tingkat sekolah menengah yang terdiri dari SMP dan SMA sebanyak 36 isian informan, disusul oleh Lainya (SD) sebanyak 17 isian informan, serta lembaga kursus 11 isian informan dan lulusan Perguruan tinggi 4 isian informan. 


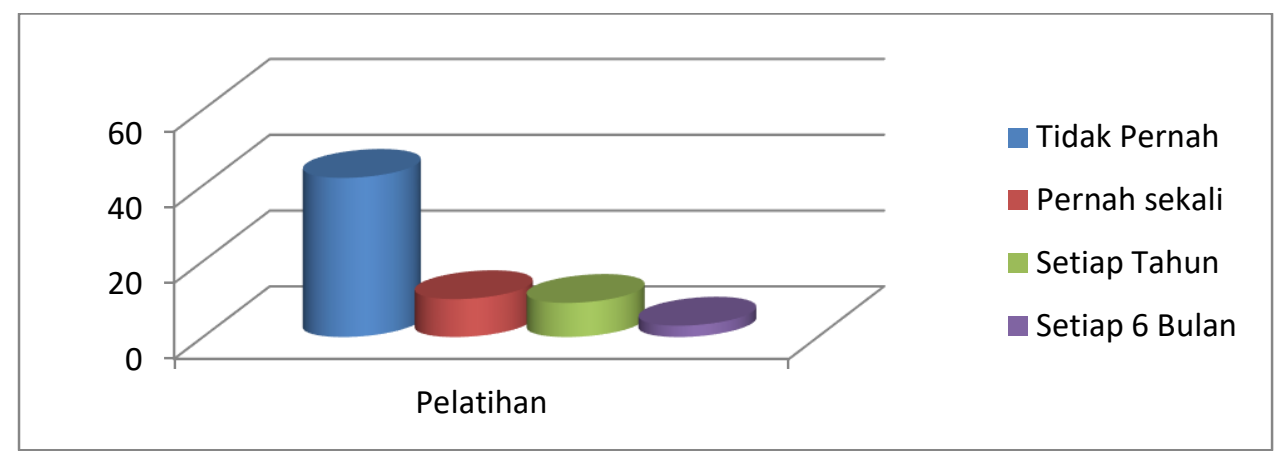

Gambar 5. Pelatihan SDM Industri Kreatif Kota Cirebon

Pelatihan bagi karyawan di kota cirebon masi sangat jarang di dapatkan oleh pelaku usaha baik pemilik maupun karyawan, hal ini terlihat dari respon para pelaku usaha kreatif dari 64 isian informan kategori pelatihan sebanyak 42 pelaku usaha tidak pernah mengikuti pelatihan dan sepuluh pelaku usaha hanya sekali mengikuti pelatihan usaha dan sisanya 9 pelaku usaha mengikuti pelatiahan tahunan dan 3 pelaku usaha yang mengikuti pelatian tiap 6 bulan.

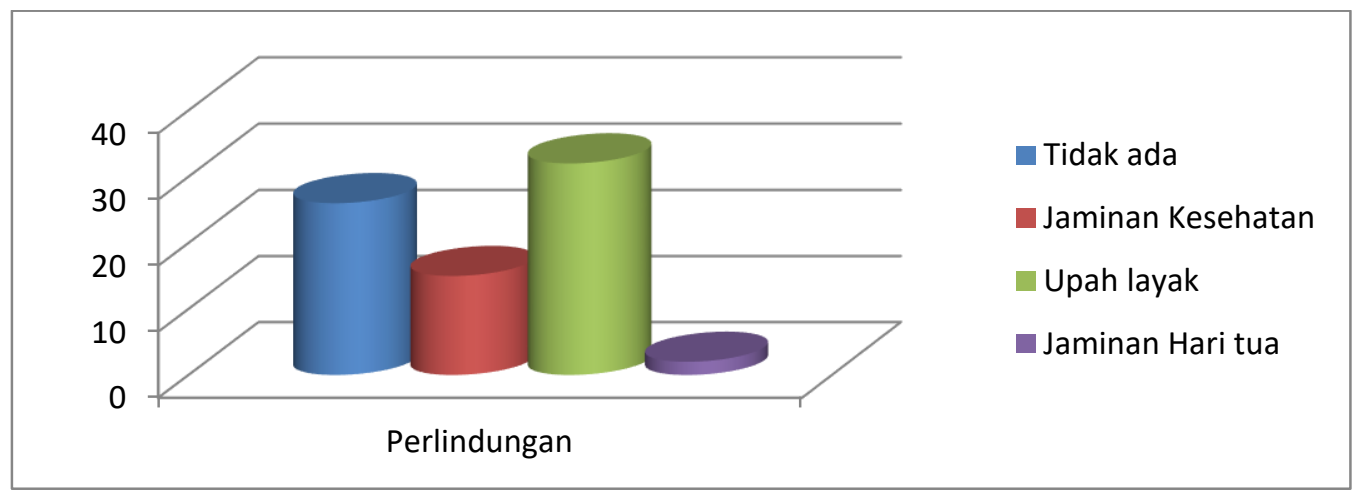

\section{Gambar 6. Tingkat Perlindungan Kerja Pelaku Industri Kreatif Kota Cirebon}

Pelaku usaha kreatif di kota Cirebon sebagaian besar belum mendaftarkan karyawanya kepada lembaga asuransi seperti BPJS dan Asuransi swasta lainya, hal ini dapat di lihat dari hasil penelitian mengenai perlindungan karyawan untuk usaha kreatif yang di lakukan kepada 75 isian informan dan dari hasil tersebut sebagian besar pelaku usaha memberikan jaminan berupa upah layak sebanyak 32 informan, sedangkan untuk Jaminan kesehatan sebayak 15 informan dan uasaha yang tidak memiliki perlindungan sebanyak 26 informan selain itu sangat sedikit dari pelaku usaha kreatif memberikan jaminan berupa jaminan hari tua hal ini di cirikan hanya 2 informan yang mengisi form jaminan hari tua.

Dari semua data yang telah dijelaskan sebelumnya dapat disimpulkan poin-poin permasalah dalam bidang SDM Indutri Kreatif Kota Cirebon yaitu ; Belum tersedianya tenaga ahli yang kompeten. Tenaga kerja yang ada (terutama tenaga lokal) memiliki skill yang terbatas, sehingga pelaku usaha memerlukan training ketika menerima tenaga kerja baru. 
Tenaga yang tersedia sebagian besar yaitu tenaga praktek dari sekolah/PT yang masih belajar, sedangkan tenaga ahli biasanya bekerja diperusahaan yang lebih besar sehingga perusahaan kecil relatif sulit mencari tenaga ahli. Tenaga yang ada belum maksimal dalam mengikuti perkembangan teknologi. Tidak adanya kurikulum sekolah mengenai tentang seni atau minimnya sekolah seni, sehingga sulit mencari tenaga pengrajin seni lukis kaca. Kurangnya tenaga kerja menyebabkan pengadaan produk menjadi terbatas dan tidak dapat memenuhi permintaan. Sulitnya mencari tenaga marketing yang bagus. Minimnya lembaga kursus/pelatihan untuk subsektor ekonomi kreatif tertentu.

\section{Kategori Bahan Baku}

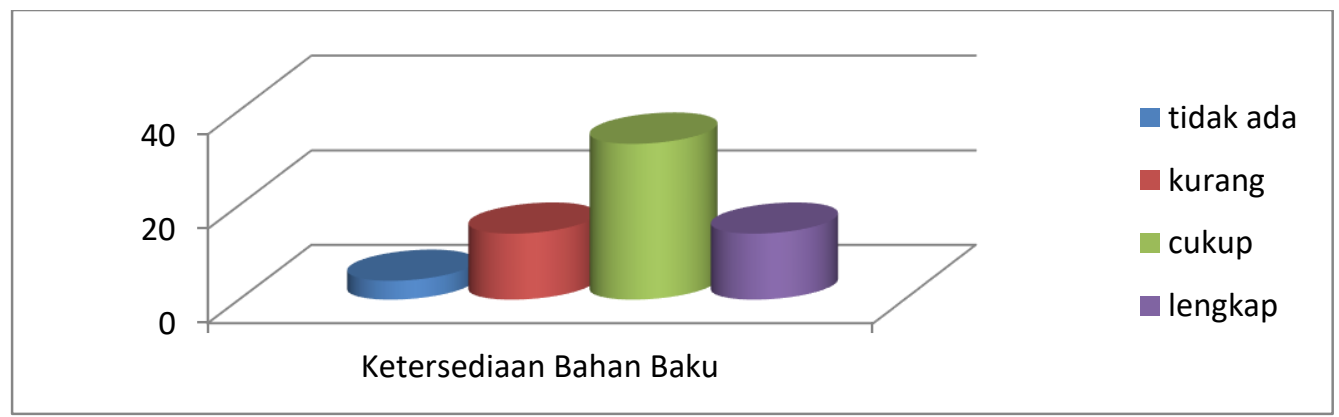

Gambar 7. Tingkat Ketersediaan Bahan Baku Lokal Industri Kreatif Kota Cirebon

Ketersediaan bahan baku di kota cirebon masih mencukupi untuk menunjang industri kraetif di kota cirebon, hal ini terlihat dari jumlah issian kuesioner yang di sajikan dalam bentuk data, data di atas menunjukan ketersediaan bahan baku pada umumnya masih mencukupi. Namun terdapat pula bahan baku yang langka seperti bahan baku untuk industri kerajinan yang menggunakan bahan-bahan inport, serta kurangnya bahan baku bagi industri kriya.

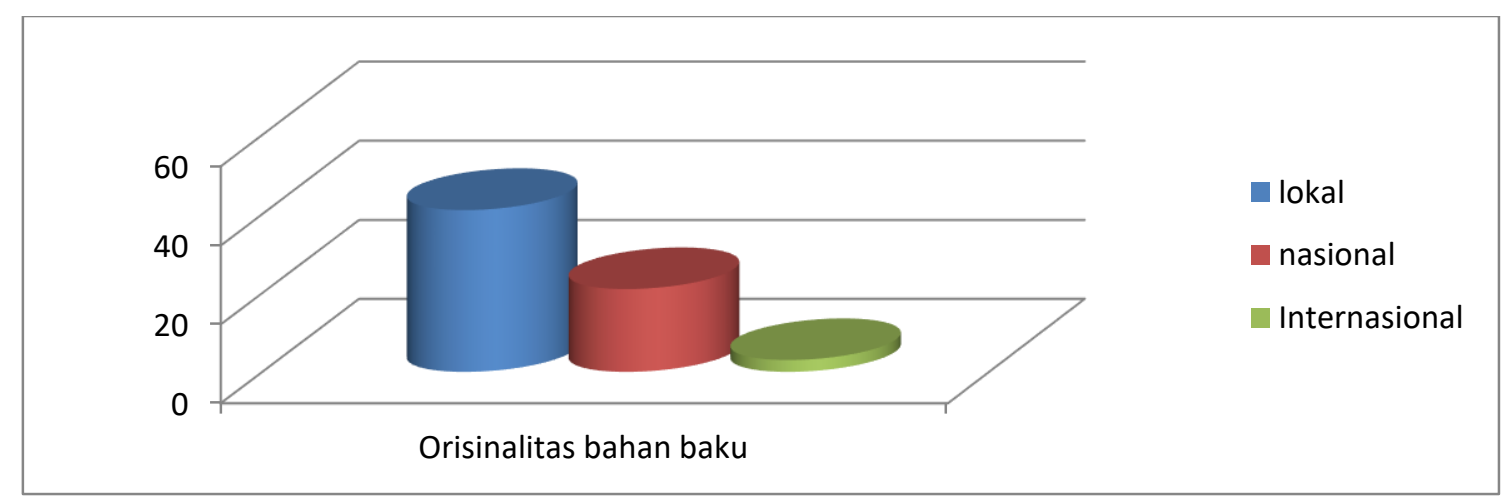

Gambar 8. Tingkat Orisinilitas bahan baku Industri Kreatif Kota Cirebon

Orisinalitas bahan baku merukapan keaslian dari geografis mana bahan baku itu di peroleh, jika bahan baku yang di peroleh berasal dari lokal maka dapat di pastikan para At-Tijaroh : Jurnal Ilmu Manajemen dan Bisnis Islam, Volume 6, Nomor 2 Tahun 2020 http://jurnal.iain-padangsidimpuan.ac.id/index.php/attijaroh 
pelaku usaha tidak akan mendapati kekurangan atau biaya kirim yang tinggi. Dari tabel di atas di ketahui bahwa pelaku usaha kreatif di kota cirebon sebagian besar berasal dari lokal, dari total isian form bahan baku berjumlah 65 isian informan dengan hasil 41 isian informan menggambarkan bahwa produksi menggunakan bahan baku lokal, 21 isian informan menggunakanbahan baku dari luar daerah yang ada diseluruh indonesia (nasional) dan 3 isian informan lainya menggunakan bahan baku import.

Dari hasil penelitian dan analisis permasalahan bahan baku, maka dapat disimpulkan poin-poin permasalahan tersebut sebagai berikut ; Kualitas bahan baku kurang terjaga, sehingga terkadang pelaku usaha mendapat bahan baku dengan kualitas jelek. Beberapa pelaku usaha kesulitan mendapatkan bahan baku berkualitas dari sekitar wilayah Cirebon (lokal) sehingga terpaksa mengambil bahan baku dari luar kota (misalkan Jakarta). Bahan baku terkadang sulit didapatkan (contohnya kelangkaan garam dan gula bagi pengusaha kecap, dan kayu jati untuk pengrajin meubel). Tidak stabilnya harga bahan baku. Kurangnya modal untuk membeli bahan baku. Sehingga pelaku usaha sering mengandalkan uang DP untuk mengadakan bahan baku.

\section{Industri}

Untuk industri usaha kreatif di kota cirebon setiap usaha memproduksi produk-produk yang berbeda dalam satu usaha ada yang memproduksi satu jenis produk saja dan ada juga usaha yang memproduksi berbagai macam produk.

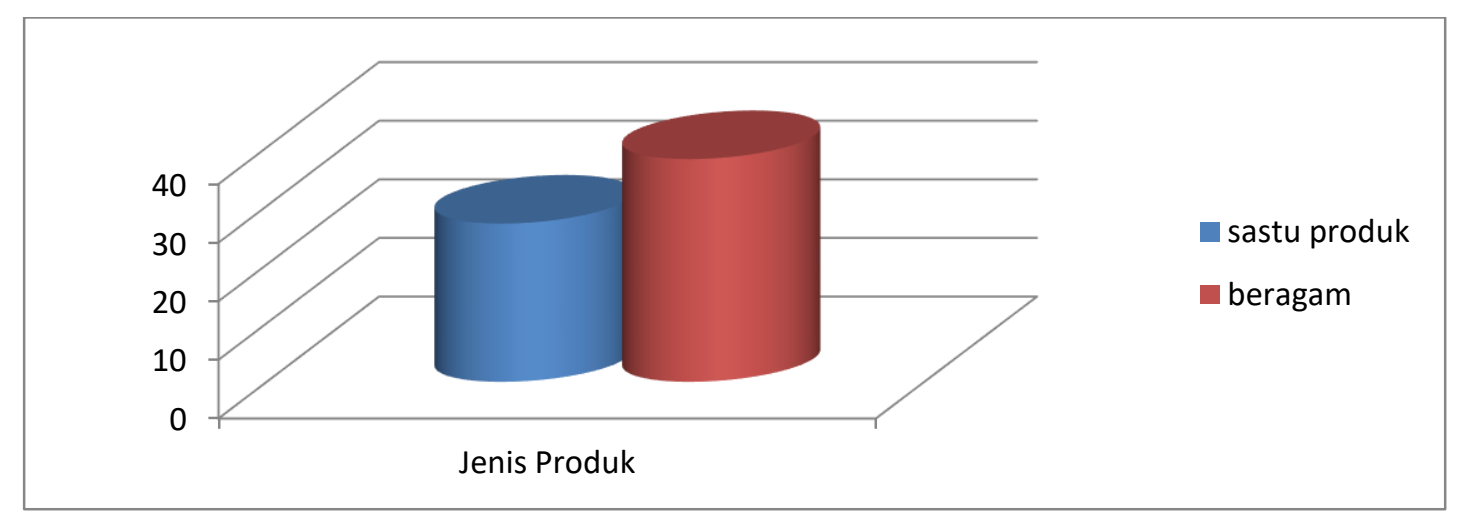

Gambar 9. Jenis Produk Industri Kreatif Kota Cirebon

Dari jumlah koesioner isian informan mengenai jenis produk yang bertotal 65 isian 27 isian informan diantaranya memproduksi satu jenis produk dan 38 isian informan memproduksi berbagai macam produk dalam satu jenis usaha. Disini dapat diketahui bahwa telah terjadi diversifikasi produk oleh para pelaku usaha industri kreatif dalam rangka untuk meningkatkan kualitas dan pengembangan usaha. Dari hasil penelitian ini maka permasalahan industri terfokus pada dua hal yiatu ; Tempat indutri atau pembuatan produk masih sempit. Penataan wilayah ekonomi kreatif belum maksimal, hal tersebut dapat terlihat 
dari masih sedikitnya sentra ekonomi kreatif (contohnya Kota Cirebon belum memiliki pusat kuliner yang berisi semua jenis makanan khas Cirebon yang terletak dalam satu kompleks).

\section{Pembiayaan}

Pembiayaan yang di maksud adalah sumber dana yang di dapat oleh pelaku usaha selama menjalankan usahanya, untuk membiayai kegiatan industrinya.

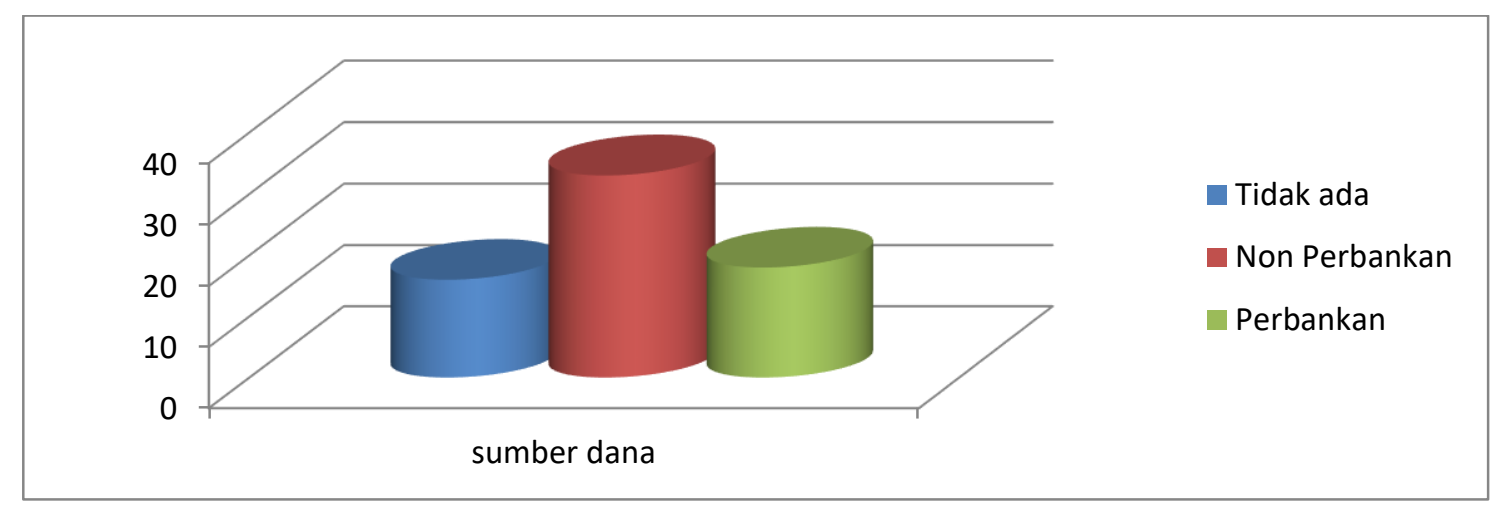

Gambar 1o. Akses Permodalan Industri Kreatif Kota Cirebon

Dari data di atas dapat di ambil kesimpulan dari total 67 isian koesioner yang di isi informan mengenai pembiayaan, sebagaian besar pelaku usaha belum menggunakan Perbankan sebagai sumber modal utama. Hal ini terlihat dari tingginya angka pengguna modal nonperbankan yang mencapai 33 isian dari informan dari total isian keseluruhan 67 isian informan, serta 16 isian menyatakan tidak menggunakan pembayaan dari pihak manapun, dan sisanya 18 isian menggunakan pembiayaan dari perbankan. Analisis data di atas dapat dapat pula menjelaskan rendahnya pengunaan pembiaya dari perbankan di karenakan paa pelaku usaha menggunakan dana talangan/ down payment yang di berikan oleh para konsumen. Dari data dan analisis tersebut, maka permasalahan pembiayaan pada industri kreatif terpusat pada ; Beberapa pelaku usaha yang membutuhkan tambahan modal kesulitan mencari sumber pendanaan. Sebagian pelaku usaha kesulitan meminjam dana dari bank, atau belum memahami bagaimana caranya mengajukan peminjaman modal di bank. Sehingga beberapa pelaku usaha memilih alternatif pendanaan dari rentenir. Masih banyak pelaku usaha yang mengandalkan modal sendiri.

\section{Akses Perluasan Pasar}

Akses pemasaran dan potensi pengembangan usaha

Akses perluasan pasar merupakan indikator kemampuan sebuah usaha untuk mengukur sampai dimana jangkauan pemasaran produknya. Semakin luas jangakauan pemasaranya maka akan berbanding lurus dengan semakin meningkatnya pendapatan usaha. 


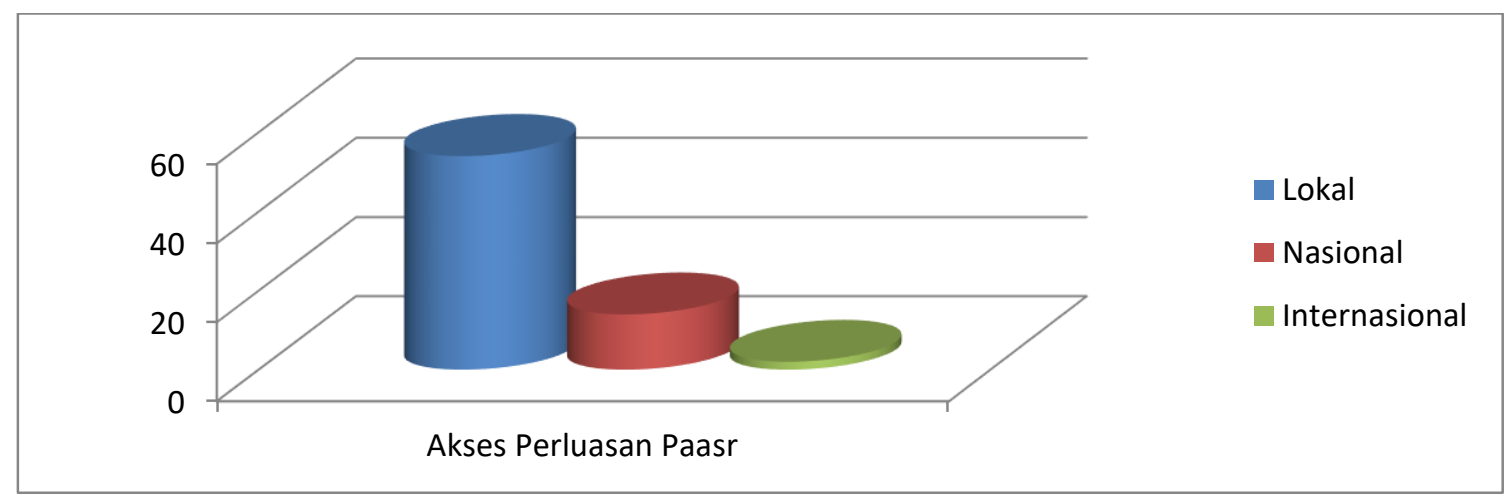

Gambar 11. Akses Permodalan Industri Kreatif Kota Cirebon

Perihal perluasan pasar usaha kreatif di kota cirebon dapat dilihat dari data di atas, dari total 70 isian kuesioner oleh informan, sebagian besar pelaku usaha belum mampu mngembangkan usahanya lebih luas, hal ini terlihat dari total 70 isian kuesioner oleh informan 54 isian diantaranya hanya melakukan pemasaran di tingkat lokal yakni kota cirebon, sedang 14 isian informan diantaranya sudah mempu mencapai pasar nasional dan 2 isian informan diantaranya baru mencapai pasar internasional. Hal ini menunjukan belum mampunya pelaku usaha kreatif untuk menjangkau pangsa pasar yang lebih luas.

\section{Kegiatan promosi}

Kegiatan promosi adalah langkah awal bagi pelaku usaha untuk mengenalkan setiap produk kapada para konsumen dengan jangkauan pangsa pasar yang lebih luas, jangkauan promoi di kota cirebon terhitung masi cukup rendah/ sempit hal ini di buktikan dengan data di bawah ini:

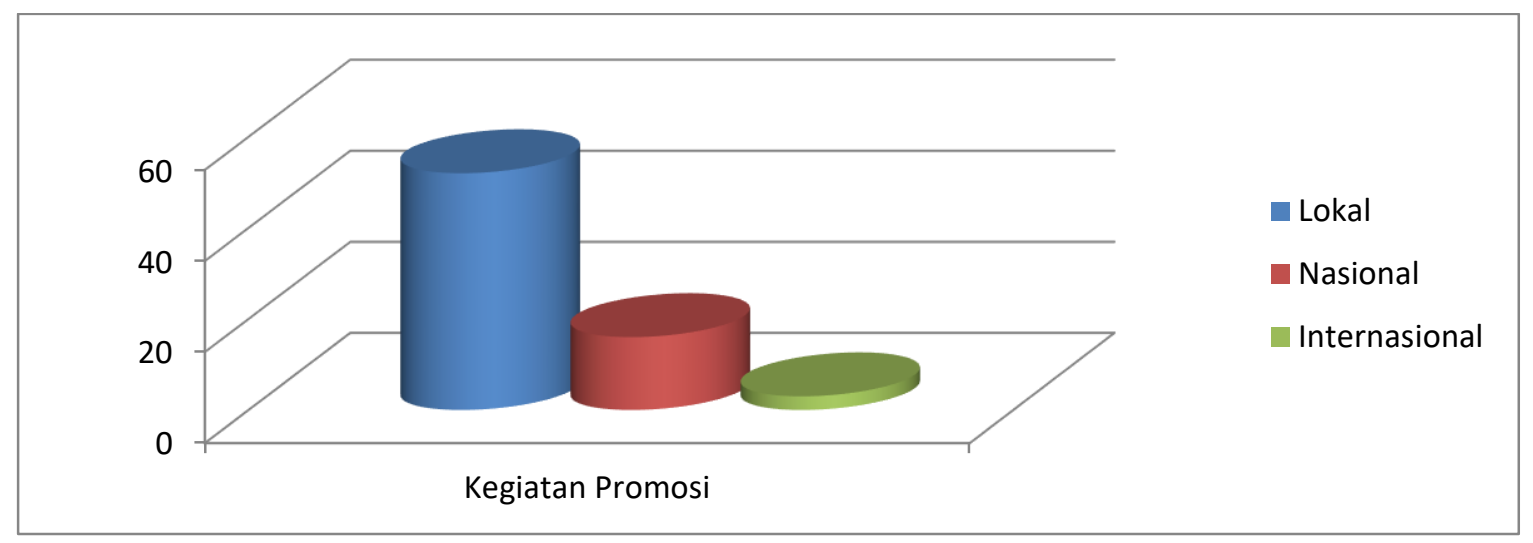

Gambar 12. Tingkat Promosi Industri Kreatif Kota Cirebon

Dari data diatas dari total kuesioner isian yang berjumlah 71 isian informan 52 isian diantaranya pelaku usaha hanya sanggup melakukan promosi produk di tingkat lokal, sedangkan untuk promosi yang menjangakau nasional baru 16 pelaku usaha serta internasional masi sangat sedikit yakni berjumlah 3 pelaku usaha. 
Dari hasil analasis terhadap permasalahan pada akses perluasan pasar, maka masalah yang dihadapi oleh para pelaku industri kreatif di Kota Cirebon adalah ; Tidak dapat mengirim pesanan diluar Kota atau pulau Jawa karena faktor jarak (khususnya usaha kuliner). Beberapa pelaku usaha masih sulit memasarkan produknya karena minimnya usaha perluasan pasar seperti membuat iklan, mengikuti bazaar dan lain-lain. Masih banyak pelaku usaha yang belum memanfaatkan internet/web/media sosial untuk memasarkan produknya. Sebagian pelaku usaha memasarkan produknya terbatas di sekitar wilayah Cirebon.

\section{Teknologi dan Infrastruktur}

\section{Perkembangan Teknologi Informatika}

Teknologi dalam masa sekarang sangat bermanfaat bagi dunia usaha terutama untuk memasarkan produk-produk usaha, dengan teknologi masyarakat dapat mengenal dengan mudah setiap produk, karena dengan teknologi jangakauan pemasaranpun dapat mencapai lingkup nasioanal dan internasional.

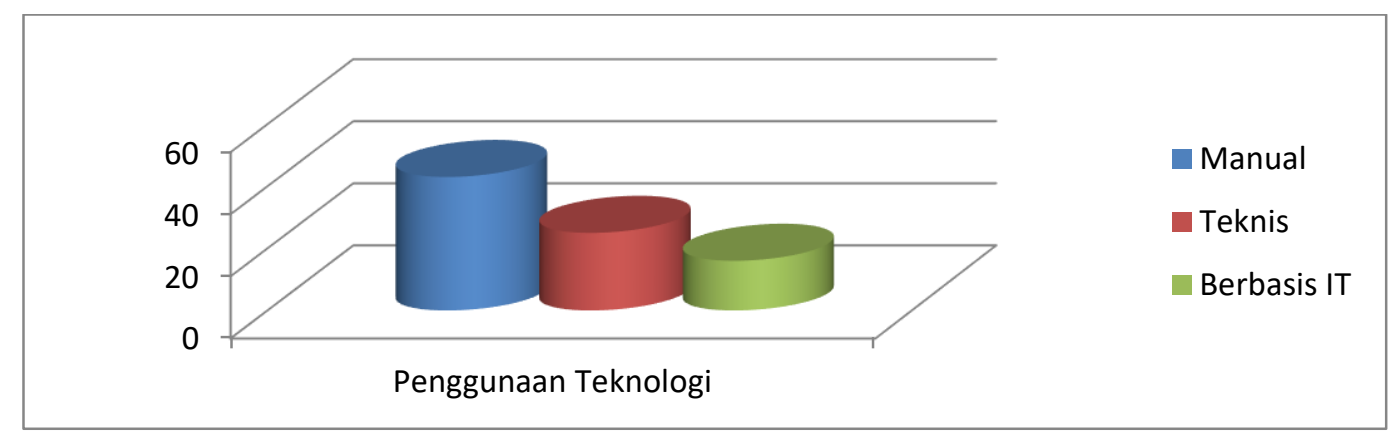

\section{Gambar 13. Tingkat Penggunaan Teknologi Informasi Industri Kreatif Kota Cirebon}

Penggunaan teknologi oleh pelaku usaha masih terhitung minim, hal ini di buktikan dengan data diatas, data di atas menjelaskan dri total 84 isian kuisioner oleh informan, 43 isian kuisioner diantaranya menggambarkan pelaku usaha masi menggunakan cara manual untuk mengelola jasa informasi dan lainya, selain itu pelaku usaha yang mengelola jasa menggunakan mekanis sekitar 25 isian kuisioner, serta 16 isian kuisioner menjelaskan pelaku usaha menggunakan teknologi informatika untuk mendukung jasa di bagian ekonomi.

\section{Infrastruktur pendukung}

Infrastruktur pendukung adalah salah satu sarana dan prasarana yang di sediakan oleh pemerintah maupun swasta untuk mendukung mobilisasinya suatu kegiatan usaha salah satunya. Dari infrastruktur yang tersedia para pelaku usaha cenderung lebih banyak menggunakan fasilitas berupa infrastruktur logistik, infrastruktur komunikasi dan infrastruktur lainya seperti jalan dan pasar, hal ini terlihat dari data penelitian : 


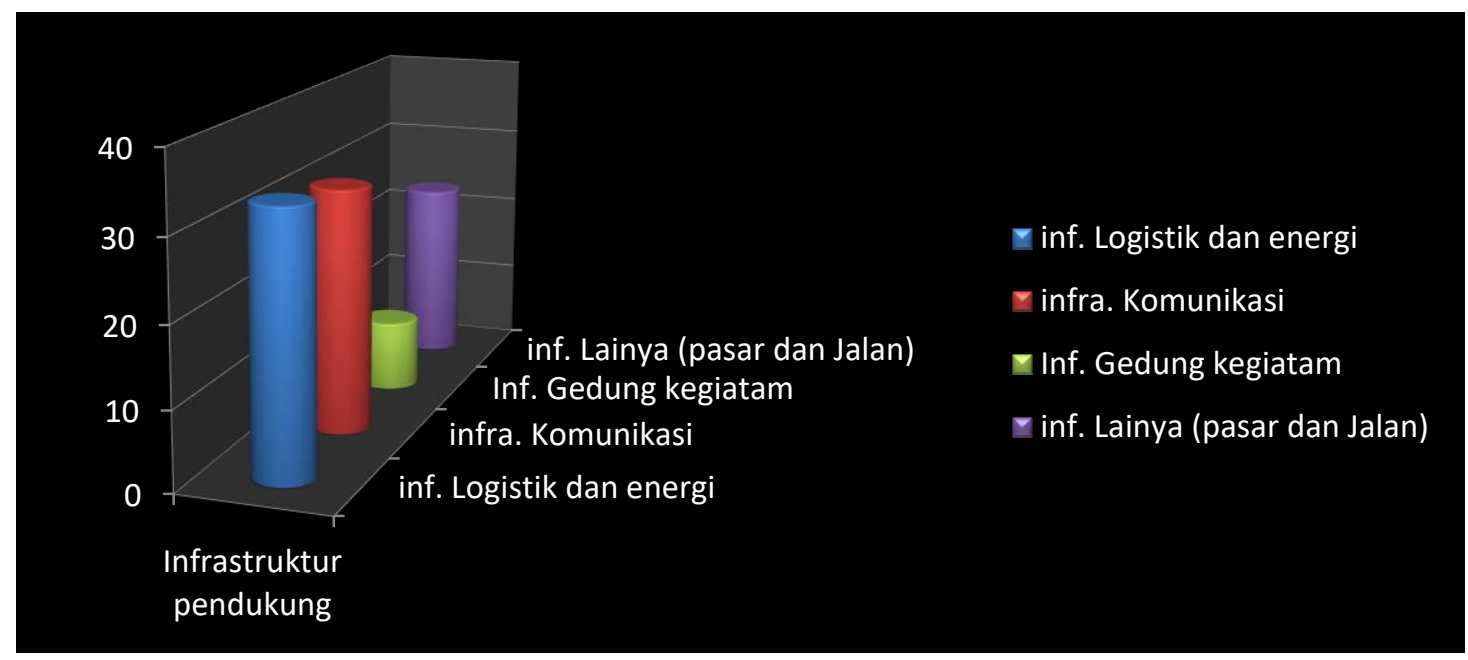

Gambar 13. Ketersediaan Infrastruktur pendukung Industri Kreatif Kota Cirebon

Dari data di atas dari seluruh isian kuesioner yang berjumlah 96 isian informan sebagaian besar pelaku usaha masih menggunakan infrastruktur logistik dan energ sebanyaki 33 pelaku usaha, serta 31 pelaku usaha menggunakan infrastruktur komunikasi dalam mendukung kegiatan usahanya, di susul dengan penggunaan infrastruktur lainya (jalan dan pasar) dengan isian 23 pelaku usaha yang menggunakan pasar dan jalan sebagai fasilitas pendukung dalam menjalankan kegiatan usahanya. Dan infrastruktur pendukung seperti gedung kegiatan hanya 9 pelaku usaha yang menggunakan gedung kegiatan sebagai sarana dalam menjalankan usahanya. Permasalahan pada penguasaan dan penggunaan teknologi dan ketersediaan infrastruktur pendukung industri kreatif di Kota Cirebon berpusat pada ; Belum semua pelaku usaha menggunakan teknologi terkini (modern) dalam pembuatan produknya. Kurangnya modal untuk membeli mesin-mesin modern untuk produksi. Banyak pelaku usaha yang belum memanfaatkan akses internet. Masih sedikit sentra ekonomi kreatif yang ada di Kota Cirebon. Akses jalan masih terbatas dibeberapa tempat ekonomi kreatif (masih banyak jalan yang harus diperbaiki dan ditata ulang). Kebutuhan listrik PLN cukup tinggi, namun pemadaman listrik bergilir masih sering terjadi.

\section{Kelembagaan}

Aspek kelembagaan merupakan aspek yang mendukung mengenai berjalannya sebuah unit usaha secara kelembagaan baik secara regulasi maupun keaktifan lembaga tersebut dalam dunia ekonomi, yang bertujuan untuk melindungi dan mengembangkan pertumbuhan dan perkembangan secara kelembagaan. Aspek kelambagaan ini dapat di lihat dari beberapa komponen sebagai berikut : 


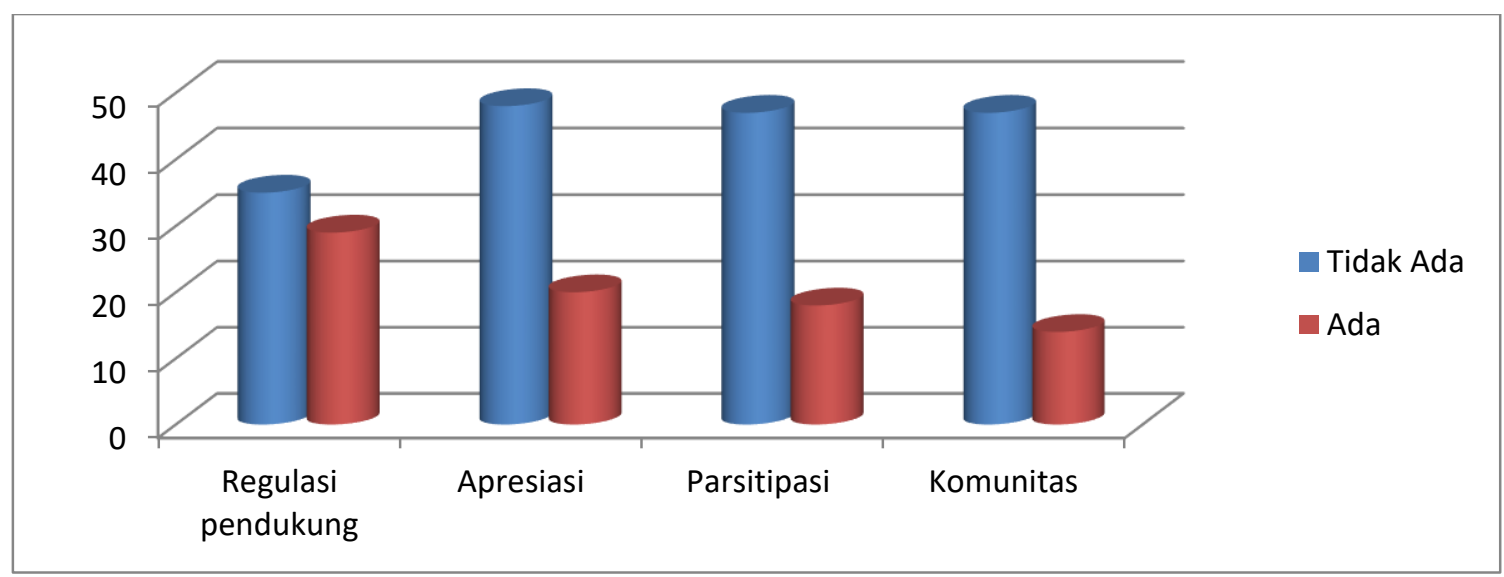

Gambar 14. Dukungan Kelembagaan Industri Kreatif Kota Cirebon

Aspek Regulasi pendukung, dimana regulasi pendukung merupakan sebuah aturan yang melegalkan dan menjaga usaha bagi si pemilik usaha secara hukum, dari data diatas hal yang menyangkut regulasi di ketahui belum semua jenis usaha mempunyai payung hukum hal ini di lihat dari total 64 pelaku usaha baru 29 jenis usaha/pelaku yang mempunyai payung hukum dan 35 jenis usaha belum mempunya payung hukum. Sedangkan, aspek apresiasi merupakan bentuk pengakuan, kegiatan fasilitas dan bentuk penghargaan dari pemerintah daerah kapada pelaku usaha atas produktivitas usahanya. Dari data diatas dapat di lihat apresiasi yang di berikan oleh pemerintah masih rendah, dari total 68 pelaku usaha baru 20 pelaku usaha yang mendapatkan apresiasi dari pemerintah dan sisanya sejumlah 48 pelaku usaha tidak mendapatkan apresiasi.

Aspek Parsitipasi, dari data di atas menunjukan rendahnya parsitipasi para pelaku usaha dalam berbagai macam even atau kegiatan-kegiatan yang diadakan oleh pemerintah ataupun oleh sewasta , dari tabel diatas dari total 65 pelaku usaha hanya 18 pelaku usaha yang ikut parsitipasi dalam acara acara bazar dan sisanya parsitipasi pelaku usaha dalam berbagai macam event masi sangat rendah dari 65 pelaku usaha 47 pelaku usaha tidak pernah ikut dalam parsitipasi dalam acara-acara bazar dan acara lainya baik yang diselenggarakan oleh pemerintah maupun swasta. Aspek Komunitas, wadah pelaku usaha kreatif di kota cirebon masih sangat minim, sehingga para pelaku usaha rendah dalam sisi jaringan usaha dan komunikasi, hal ini dapat di lihat dari data hasil penelitian diatas, data diatas menunjukan bahwa dari total 61 pelaku usaha yang mengisi kuisioner komunitas hanya 14 pelaku usaha yang sudah memiliki wadah / komunitas usaha dan sisanya sebanyak 47 pelaku usaha belum mempunya komunitas/wadah untuk mendukung kegiatan usahanya.

Dari analisis terhadap permasalahan yang dihadapi para pelaku usaha pada aspek kelembagaan. Hal ini sejalan dengan penelitian terdahulu (Rismawati, 2018). Dapat disimpulkan masih ada usaha yang belum memiliki izin atau SKU Kota Cirebon. Meskipun hal ini juga sudah dibantah oleh Menteri Koperasi dan UMKM AA Gede Ngurah Puspayoga 
mengatakan dimana pemerintah akan melakukan revisi atas Perpres Nomor 98 Tahun 2014 tentang izin usaha mikro dan kecil sehingga tidak diperlukan lagi izin cukup mendaftar saja. (Usaha Mikro Dan Kecil Tak Perlu Lagi Izin Usaha, Cukup Mendaftar, n.d.). Namun pada kenyataanya masih diperlukan izin di Kota Cirebon. Selain itu, masih ada pelaku usaha yang belum tergabung dalam komunitas. Beberapa pelaku usaha mengeluhkan minimnya informasi mengenai UMKM. Hal ini didukung juga oleh penelitian terdahulu (Sudaryanto \& Wijayanti, 2013). Ada beberapa subsektor ekonomi kreatif yang belum memiliki komunitas atau organisasi yang menaunginya (khususnya di Kota Cirebon). Minimnya informasi terkait komunitas bertaraf nasional dan internasional. Kemitraan dapat diperoleh jika pelaku usaha bergabung dengan berbagai komunitas yang ada. Kemitraan sangat penting bagi pelaku usaha (Lantu et al., 2016). Hal tersebut akan mendukung peningkatan daya saing pelaku usaha (Ratnasari, 2016).

\section{KESIMPULAN}

Permasalahan yang paling utama yang di alami oleh pelaku usaha adalah SDM yang tidak sesuai dengan pekerjaan di karenakan latar belakang pendidikan yang rendah, kurangya pelatihan sehingga dampak pada karyawanya sendri adalah kurangnya produktivitas kinerja. Hal ini memberikan gambaran bagi pemerintah Kota Cirebon untuk melakukan langkahlangkah penanganan dengan lebih meningkatkan kualitas SDM misalkan dengan menyelenggaran pelatihan-pelatihan dan tempat-tempat kursus keahlian, sehingga masalah tenaga SDM yang kurang kompeten dapat segera teratasi.

Sebagian pelaku usaha mendapatkan permasalahan dalam sektor permodalan, para pelaku usaha masih sedikit yang menggunakan jasa perbankan dalam pemenuhan kebutuhan modalnya, di karenakan masih menggunakan dana talangan atau DP, sehingga para pelaku usaha kurang maksimal dalam produktivitasnya. Masalah permodalan dan akses pelaku usaha untuk memperoleh pembiayaan ke bank dapat diberikan solusi dengan mengadakan sosialisasi dan pelatihan bagi pelaku usaha tentang bagaimana mengelola usaha dan keuangan yang baik, sehingga usaha yang mereka lakukan dapat memperoleh akses ke permodalan bank. Selain itu juga pemerintah Kota Cirebon dapat mengadakan kerjasama dengan pihak perbankan se wilayah Kota Cirebon agar memberikan kemudahan atupun subsidi bagi pelaku usaha yang memiliki potensi dan prospek baik.

Kurangya komunitas serta wadah untuk menampung usaha membuat para pelaku usaha sulit untuk mengembangkan usahanya hal tersebut di karenakan tidak adanya rekan yang seprofesi dan se usaha sehingga kurangya komunikasi dan saling tukar informasi sesama pelaku usaha, baik informasi pasar serta informasi lainya. Komunitas dapat menjadi wadah bagi para pengusaha untuk saling berbagi pengalaman dan permasalahan sehingga antara satu dengan yang lainnya saling melengkapi. Pemerintah Kota Cirebon dapat membentuk 
komunitas-komunitas pelaku industri kreatif sesuai dengan jenis usaha masing-masing sehingga dapat mempermudah akses dan informasi bagi para pelaku usaha dalam menjalankan usahanya.

Keterbatasan akses usaha adalah salah satu faktor dari kurangya jaringan serta informasi yang di peroleh sehingga pelaku usaha hanya mengetahui pangsa pasar bersekala lokal, serta ketidak tahuan pelaku usaha mengenai peluang di wilayah lain. Akses pasar sangat berpengaruh pada pendapatan usaha, semakin luas pangsa pasar yang mampu di jangkau maka semakin besar pendapatn usaha yang di dapatkan. Pemerintah dapat berperan memberikan solusi dengan mengadakan kegiatan-kegiatan yang bersifat promosi seperti mengadakan event-event dan pameran-pameran yang dapat mengundang turis domestik maupun mancanegara berkunjung sekaligus berwisata ke Kota Cirebon.

Penggunaan teknologi dalam menjalankan usahanya sangat mempunyai pengaruh besar terhadap produktivitas dan kualitas barang yang dihasilkan, selain itu dengan adanya teknologi dapat menghemat waktu peroduksi serta menghemat biaya, sebuah usaha yang tidak di dukung oleh teknologi baik itu teknologi produksi dan teknologi impormasi maka usaha tersebut akan kalah saing dalam hal pemenuhan kebutuhan pasar serta kalah saing dalam mendapatkan informasi. Dalam hal ini peran pemerintah Kota Cirebon dapat berupa memberikan informasi terkait dengan aplikasi teknologi terbaru bagi para pelaku usaha kreatif atau bila memungkinkan juga memberikan bantuan riil berupa alat atau media untuk menunjang produktivitas para pelaku usaha.

\section{DAFTAR PUSTAKA}

1. Letak Geografis - Pemerintah Daerah Kota Cirebon. (n.d.). Retrieved December 29, 2020, from https://www.cirebonkota.go.id/profil/cirebon-dalam-angka/1-letak-geografis/

Asyhari, \& Wasitowati. (2015). HubunganTriple Helix, Inovasi, KeunggulanBersaing dan Kinerja. Conference in Business, Accounting and Management, 2(1), 320-334. https://doi.org/23029791

Ayu Monica, C., Marwa, T., \& Yulianita, A. (2019). Analisis potensi daerah sebagai upaya meningkatkan perekonomian daerah di Sumatera Bagian Selatan. Jurnal Ekonomi Pembangunan, 15(1), 60-68. https://doi.org/10.29259/jep.v15i1.8825

Berita-E-Commerce untuk UMKM Dan Pertumbuhan Ekonomi Indonesia. (n.d.). Retrieved December 29, 2020, from https://bppk.kemenkeu.go.id/content/berita/pusdiklatkeuangan-umum-ecommerce-untuk-umkm-dan-pertumbuhan-ekonomi-indonesia2019-11-05-ebe6e220/

Burhanudin, M. (2020). Analisis Perkembangan Industri Kreatif di Indonesia [Thesis, IPB University]. http://repository.ipb.ac.id/handle/123456789/102952 
Erimurti, K. (2008). Eco-Design, Konsep design Produk Industri Kreatif. PPPPTK Seni dan Budaya, Yogyakarta.

Gaunt, F. M. (n.d.). Analisis Terhadap Para Pekerja Industri Kreatif di Kota Bandung. 68.

Hanya Industri Kreatif yang Bisa Berkembang di Kota Cirebon. (n.d.). Retrieved December 29, 2020, from https://bandung.bisnis.com/read/20150302/549/1061807/hanyaindustri-kreatif-yang-bisa-berkembang-di-kota-cirebon

HIPMI Dorong Pengembangan Industri Kreatif di Cirebon | Ekonomi. (2017, April 6). Bisnis.Com. https://ekonomi.bisnis.com/read/20170406/87/643159/hipmi-dorongpengembangan-industri-kreatif-di-cirebon

Lantu, D. C., Triady, M. S., Utami, A. F., \& Ghazali, A. (2016). Pengembangan model peningkatan daya saing UMKM di Indonesia: Validasi kuantitatif model. The Asian Journal of Technology Management, 15(1), 77.

McMurtry, S. L., Kettner, P. M., \& Netting, F. E. (1993). Strategic choices made by nonprofit agencies serving low-paying clients. Community organization and social administration: Advances, trends and emerging principles. New York: Haworth Press.

Moleong, L. (2005). Metodologi Penelitian Kualitatif. Rosda.

Negara, K. S. (n.d.). SBY: Kembangkan Ekonomi Gelombang Keempat | Sekretariat Negara. $\begin{array}{llll}\text { Retrieved December 28, 2020, from } & \text { 28 }\end{array}$ https://www.setneg.go.id/baca/index/sby_kembangkan_ekonomi_gelombang_kee mpat

Ratnasari, E. D. (2016). Mengubah Tantangan Menjadi Peluang UMKM Indonesia dalam Menghadapi MEA 2015. Jurnal REP (Riset Ekonomi Pembangunan), 1(1), 49-60.

Rismawati, N. (2018). Profil UMK, Permasalahand an Upaya Pemberdayaannya di Kabupaten Sumedang. Coopetition, 9(1), 13-30.

Siwu, H. F. D. (2019). STRATEGI PERTUMBUHAN DAN PEMBANGUNAN EKONOMI DAERAH. JURNAL PEMBANGUNAN EKONOMI DAN KEUANGAN DAERAH, 19(3). https://doi.org/10.35794/jpekd.16464.19.3.2017

Sudaryanto, R., \& Wijayanti, R. R. (2013). Strategi pemberdayaan UMKM menghadapi pasar bebas Asean. Pusat Kebijakan Ekonomi Makro. Badan Kebijakan Fiskal. Kementerian Keuangan, Jakarta.

Usaha Mikro dan Kecil Tak perlu Lagi Izin Usaha, Cukup Mendaftar. (n.d.). Retrieved December 29, 2020, from https://money.kompas.com/read/2016/o3/10/175500226/Usaha.Mikro.dan.Kecil.Ta k.perlu.Lagi.Izin.Usaha.Cukup.Mendaftar 